\title{
Pandangan dan Pengalaman Dosen UIN Alauddin Makassar dalam Upaya Mengantisipasi Gerakan Islam Radikal di Kalangan Mahasiswa
}

\author{
Arifuddin \\ Universitas Islam Negeri Alauddin Makassar \\ arifuddin.uinalauddin@yahoo.co.id
}

\begin{abstract}
This article is intended to fill the gap scholarly studies about radical movements in the university environment. This study is a qualitative research with phenomenological approach involving six (6) lecturers of UIN Alauddin Makassar as a research subject. From the interviews, it has been found out that the lecturers had the same view of radicalism in terms of positive and negative. Apparently, radicalism is growing because it begins with less understanding of religious thoughts among students which is triggered by their immature pattern of thinking as well as their great curiosity. Basically, all respondents consider this issue is a serious and often discussed with their students. Universities and lecturers, therefore, are encouraged to direct and guide the students to avoid the development of radical ideologies.
\end{abstract}

\begin{abstract}
Abstrak
Artikel ini dimaksudkan untuk mengisi kesenjangan keilmiahan tentang gerakan radikal di lingkungan kampus. Studi ini adalah penelitian kualitatif dengan pendekatan fenomenologi melibatkan enam (6) orang dosen UIN Alauddin Makassar sebagai subjek penelitian. Dari hasil wawancara, ditemukan bahwa dosen memiliki pandangan yang sama tentang radikalisme dari segi positif dan negatifnya. Paham radikalisme ini berkembang karena diawali dengan pemahaman agama yang tidak mendalam dan di kalagan mahasiswa, perkembangannya difasilitasi oleh masih belum matangnya pola berfikir mahasiswa serta adanya keingintahuan yang besar. Pada dasarnya, seluruh responden menganggap isu ini adalah hal yang serius dan sering dibahas bersama mahasiswa. Perguruan tinggi dan para dosen juga didorong untuk mengarahkan dan membimbing mahasiswa agar terhindar dari perkembangan paham-paham radikal.
\end{abstract}

Keywords; view, experience, lecturer, students, Islamic radical movements, prevention. 


\section{A. Pendahuluan}

Di era reformasi Indonesia yang mengedepankan kebebasan berekspresi dan keterbukaan dalam berbagai aspek kehidupan saat ini, masyarakat Indonesia telah sering dihadapkan pada berbagai gerakan Islam yang cukup radikal. Istilah radikal ini diberikan karena dalam beberapa kejadian, pengikut dari gerakan tertentu melakukan aksi-aksi yang menurut sebagian besar masyarakat tergolong kasar dan merugikan orang banyak. Aksi anarkis tersebut dianggap sebagai akibat dari adanya ketimpangan antara harapan yang diajarkan dalam pemahaman agama mereka dengan realita-realita yang ada di masyarakat. Di sisi lain, kekuatan-kekuatan sosial dan politik yang berlaku tidak memungkinkan untuk menyelesaikan realita-realita tersebut secara cepat dan tepat. ${ }^{1}$

Bahaya radikalisme telah memberi ancaman yang nyata di seluruh dunia, termasuk Indonesia. Beberapa kejadian kekerasan yang mengatasnamakan agama dan ingin menegakkan negara Islam di dalam Negara Kesatuan Republik Indonesia (NKRI) telah meresahkan masyarakat dan bahkan telah banyak menelan korban jiwa dalam beberapa kejadian. Peristiwa "Bom Bali I dan II", dan terakhir aksi terror "Bom Sarinah" yang diklaim dilakukan oleh beberapa kelompok Islam radikal memberikan peringatan bahwa gerakan-gerakan yang mengusung kekerasan ini adalah gerakan yang tidak boleh dipandang sebelah mata. Menyikapi hal ini, Presiden Republik Indonesia menekankan bahwa organisasi kemasyarakatan harus menjadi benteng untuk gerakan radikalisme. ${ }^{2}$ Sebagai organisasi kemasyarakatan terbesar di Indonesia, Nahdlatul Ulama (NU) dapat mengambil peranan agar pandanganpandangan NU tentang praktik keagamaan, sikap-sikap sosial, dan sikapsikap kemasyarakatan mampu didiseminasi dan disebarluaskan, baik di internal maupun eksternal bangsa. ${ }^{3}$ Selain itu, peranan yang sama juga sangat diharapkan dari organisasi kemasyarakatan lain, Majelis Ulama Indonesia (MUI) dan Muhammadiyah, yang telah menjadi rujukan umat

\footnotetext{
1 Afadlal, Awani Irawati, Dhurorudin Mashad, Dundin Zaenuddin, Dwi Purwoko, Endang Turmudi, Muhammad Hisyam, \& Riza Sihbudi, Islam dan Radikalisme di Indonesia. (Jakarta: LIPI Press, 2005), hal. 1

${ }^{2}$ CNN Indonesia (Kontributor: Resty Armenia), Bahas Radikalisme, Jokowi Minta NU Jadi Benteng, 26/2/2015. Diakses pada tanggal 16 Juli 2016 dari http://www.cnnindonesia.com/politik/20150226135404-32-35102/bahas-islam-radikaljokowi-minta-nu-jadi-benteng/

${ }^{3}$ Ibid.
} 
Islam di Indonesia, dan dianggap sebagai penghalang terbesar bagi perkembangan gerakan-gerakan Islam radikal. ${ }^{4}$

Salah satu tantangan utama yang dihadapi bangsa Indonesia berkaitan dengan perkembangan gerakan radikal tersebut adalah berkembangnya ideologi radikal di dalam lingkungan perguruan tinggi dengan menjadikan mahasiswa sebagai target. Dalam beberapa media termasuk CNN Indonesia ${ }^{5}$, dijelaskan bahwa paham radikalisme telah berkembang pesat di dalam dunia kampus. Kampus dalam beberapa kesempatan telah dijadikan sebagai tempat kaderisasi dimana mahasiswa didoktrin untuk mengikuti paham radikal seperti khilafah. ${ }^{6}$ Salah satu narasumber yang pernah menjadi pengikut salah satu organisasi radikal menyebutkan bahwa doktrinisasi ("cuci otak") paham radikal terjadi saat menjadi mahasiswa, yang kemudian dilanjutkan dengan kegiatan pelatihan militer. $^{7}$ Lebih lanjut, salah satu peneliti Lembaga Ilmu Pengetahuan Indonesia (LIPI) menuturkan bahwa radikalisme memang telah menyentuh mahasiswa di perguruan tinggi melalui proses perekrutan yang tertutup dan terorganisir, dan hal tersebut dapat berpotensi memecah belah bangsa (Anas Saidi dikutip dalam CNN Indonesia, 2016). Permasalahan besarnya adalah, kelompok-kelompok ini memiliki pandangan keyakinan dan sikap fundamentalisme yang kaku, selalu merasa paling benar dan memiliki tujuan membangun negara Islam, yang untuk mewujudkannya dibolehkan menggunakan cara-cara kekerasan (Endang Turmudi/ peneliti LIPI dikutip dalam CNN Indonesia, 2016). ${ }^{8}$

Untuk mencegah berkembanganya gerakan radikal yang mengusung kekerasan sebagai bentuk aktivitas pergerakan, pihak kampus

4 UIN Syarif Hidayatullah, MUI, NU, Muhammadiyah Jadi Musuh Gerakan Islam Radikal. 6/2/ 2016. Diakses pada tanggal 10 Juli 2016 dari http://www.uinjkt.ac.id/id/mui-nu-muhammadiyah-jadi-musuh-gerakan-islam-radikal/

5 CNN Indonesia (Kontributor: Prima Gumilang), Radikalisme Ideologi Menguasai Kampus. 18/2/2016. Diakses pada tanggal 30 Juli 2016 dari http://www.cnnindonesia.com/nasional/20160218193025-12-111927/radikalismeideologi-menguasai-kampus/

${ }^{6}$ Unair News, Kampus Jadi Tempat Kaderisasi Paham Radikal, 26/3/2016. Diakses pada tanggal 1 Agustus 2016 dari http://news.unair.ac.id/2016/03/26/kampus-jadi-tempatkaderisasi-paham-radikal/

${ }^{7}$ Ibid.

8 CNN Indonesia (Kontributor: Prima Gumilang), Radikalisme Ideologi Menguasai Kampus. 18/2/2016. Diakses pada tanggal 30 Juli 2016 dari http://www.cnnindonesia.com/nasional/20160218193025-12-111927/radikalismeideologi-menguasai-kampus/ 
ataupun pergurun tinggi di Indonesia memiliki peran yang sangat penting. Penanaman ideologi Pancasila serta pendekatan agama menjadi bagian yang sangat penting untuk mencegah masuknya paham radikalisme di kampus. $^{9}$ Pembelajaran kebangsaan melalui organisasi kemahasiswaan merupakan langkah strategis, inovatif, terpadu, sistematis, serius, dan komprehensif dalam menanggulangi radikalisme. ${ }^{10}$ Di samping itu, perlu adanya suatu tempat konsultasi bagi mahasiswa di setiap perguruan tinggi dimana setiap dosen termasuk dosen pembimbing keagamaan yang memiliki kualifikasi dapat menjalankan peran konsultasi tersebut. Masih tingginya tingkat intoleransi di kalangan mahasiswa akan menyimpan benih sekam radikalisme yang masih besar yang jika tidak diatasi dapat menjadi pukulan berat bagi perguruan tinggi khususnya dan dunia pendidikan secara umum yang gagal dalam menanamkan nilai-nilai kebhinnekaan dan ideologi Pancasila terhadap mahasiswa. ${ }^{11}$

Melihat pentingnya peranan perguruan tinggi dalam menangkal berkembangnya paham radikal yang berpotensi berujung pada aktivitas kekerasan, universitas-universitas Islam di bawah naungan Kementrian Agama seharusnya turut menjalankan peran strategis dalam upaya menangkal radikalisasi. Termasuk di dalam peran tersebut adalah dengan mengantisipasi pergerakan organisasi radikal intra-kampus melalui keterlibatan dosen dengan kualifikasi pendidikan berbasis agama Islam yang memang banyak menjadi tenaga dosen ataupun pembimbing mahasiswa. Sampai saat ini, studi ataupun penelitian yang mengeksplorasi peran tenaga pendidik (dosen) dalam kaitannya dengan upaya membentengi radikalisasi ini masih terbatas. Saat ini, telah tersedia bahan

9 Kemenristekdikti. Perkuat Ideologi Pancasila dan Agama, Cegah Paham Radikal Terorisme Masuk ke Perguruan Tinggi, 29/2/2016. Diakses pada tanggal 31 Juli 2016 dari

http://www.dikti.go.id/perkuat-ideologi-pancasila-dan-agama-cegah-paham-radikalterorisme-masuk-ke-perguruan-tinggi/

${ }_{10}$ Direktorat Jenderal Pembelajaran dan Kemahasiswaan Kemenristekdikti. General Education Salah Satu Model dalam Mencegah Radikalisme di Lingkungan Perguruan Tinggi, 14/3/2016. Diakses pada tanggal 31 Juli 2016 dari http://belmawa.ristekdikti.go.id/2016/03/14/general-education-salah-satu-model-dalammencegah-radikalisme-di-lingkungan-perguruan-tinggi/

${ }^{11}$ Direktorat Jenderal Pembelajaran dan Kemahasiswaan Kemenristekdikti. General Education Salah Satu Model dalam Mencegah Radikalisme di Lingkungan Perguruan Tinggi, 14/3/2016. Diakses pada tanggal 31 Juli 2016 dari http://belmawa.ristekdikti.go.id/2016/03/14/general-education-salah-satu-model-dalammencegah-radikalisme-di-lingkungan-perguruan-tinggi/. 
bacaan dari segi perpektif historis dan sejarah Islam terkait radikalisme, akan tetapi sumber bacaan yang merupakan hasil penelitian lapangan masih sangat sedikit. Oleh karena itu, penelitian ini dilakukan untuk mengisi kesenjangan tersebut.

Rumusan masalah dalam penelitian ini adalah: "Bagaimana respon (pandangan dan pengalaman) dosen UIN Alauddin Makassar dalam upaya mengatasi perkembangan gerakan Islam radikal di kalangan mahasiswa". Rumusan masalah tersebut lebih lanjut dijabarkan melalui beberapa pertanyaan spesifik yang menjadi dasar untuk menyusun tema-tema pembahasan.

Adapun pertanyaan spesifik yang dimaksud adalah sebagai berikut: a) bagaimana pandangan responden tentang isu radikalisme yang berkembang di masyarakat, dan mahasiswa?; b) bagaimana kemungkinan proses berkembangnya gerakan-gerakan islam radikal tersebut?; c) pernahkan responden mengkat isu radikalisme ini dalam menyampaikan pesan dakwah melalui ceramah agama, atau pada pertemuan dengan mahasiswa baik dalam forum keagamaan ataupun forum keilmiahan?; d) langkah-langkah apa yang dapat ditempuh dimasa mendatang untuk mengantisipasi berkembangnya paham radikalsime di kalangan mahasiswa?

Penelitian ini bertujuan untuk memahami fenomena terkait gerakan-gerakan Islam radikal dari sudut pandang dosen sebagai penyedia informasi keagamaan/ pendidik professional bagi mahasiswa. Fenomena yang dimaksud akan dipahami dengan menjawab rumusan masalah yang telah disebutkan sebelumnya. Secara khusus, penelitian ini bertujuan: pertama, untuk mengetahui pandangan dosen tentang isu radikalisme dan perkembangan gerakannya dalam lingkungan perguruan tinggi (kalangan mahasiswa). Kedua, penelitian ini bertujuan untuk mengetahui pengalaman dosen dalam melaksanakan dan menyebarkan dakwah dalam upaya mengantisipasi berkembangnya gerakan radikalisme tersebut.

Dengan memahami fenomena tersebut, maka penelitian ini dapat berkontribusi bagi ilmu pengetahuan yang berbasis ilmiah (riset) terkait dengan isu radikalisme dengan menyediakan data terkini dari root level pendidikan. Selain itu penelitian ini merupakan satu dari sedikit penelitian yang membahas tentang isu radikalisme. Ada banyak sumber tentang radikalisme, akan tetapi sumber yang berbasis penelitian (ilmiah) masih terbatas, sehingga diharapkan hasil penelitian ini menambah khasanah dan wawasan keislaman terkait isu radikalisme dan upaya mengatasinya. 
Penelitian ini adalah penelitian lapangan (field research) dengan menggunakan metode kualitatif. Desain penelitian yang digunakan adalah pendekatan fenomenologi. Penelitian ini dilakukan di Universitas Islam Negeri (UIN) Alauddin Makassar dengan menjadikan dosen sebagai sumber data penelitian. Teknik sampling yang digunakan adalah purposive sampling dengan kriteria inklusi dosen bidang keagamaan yang sering melakukan ceramah/ menyebarkan pesan dakwah. Hal ini dikarenakan UIN Alauddin juga memiliki fakultas dari disiplin ilmu-ilmu kesehatan sehingga dosen yang berasal dari fakultas ini diekslusikan sebagai sampel penelitian. Teknik sampling ini juga dipilih karena purposive sampling memungkinkan peneliti untuk mendapatkan informasi yang memadai dari sumber yang diinginkan. ${ }^{12}$ Data dalam penelitian ini diperoleh melalui wawancara mendalam semi-terstruktur dengan alokasi waktu tiap wawancara 45-60 menit. Data yang dikumpulkan kemudian diolah dengan menggunakan thematic analysis. Metode analisis tematik adalah metode yang memungkinkan peneliti untuk mengidentifikasi, menganalisa dan melaporkan pola-pola pokok bahasan dari data yang diperoleh, dan metode ini meliputi pemahaman data, koding data, pengkategorian data serta penarikan kesimpulan dari data-data yang ada. ${ }^{13}$

\section{B. Profil singkat tempat penelitian}

Penelitian ini dilaksanakan di dalam lingkungan UIN Alauddin Makassar. UIN Alauddin Makassar adalah perguruan tinggi Islam yang dulunya bernama IAIN Alauddin Makassar yang merupakan Fakultas cabang dari IAIN Sunan Kalijaga Yogyakarta. ${ }^{14}$ Dalam perubahan status kelembagaan dari Institut ke Universitas, UIN Alauddin Makasar mengalami perkembangan dari lima (5) buah Fakutas menjadi 7 (tujuh) buah Fakultas termasuk di dalamnya Fakultas Kedokteran dan Ilmu Kesehatan, serta 1 (satu) buah Program Pascasarjana (PPs) berdasarkan

\footnotetext{
12 Michelle Cleary, Jan Horsfall, \& Mark Hayter, Data Collection and Sampling In Qualitative Research: Does Size Matter?, Journal of Advanced Nursing, Vol.70, No.3. 2014, 473-475.

13 Pranee Liamputtong, Qualitative Research Methods .(Edisi ke-4, Melbourne: OXFORD University Press, 2013), hal.23

${ }^{14}$ UIN Alauddin Makassar. Profil UIN Alauddin Makassar. Diakses pada tangal 1 Juli 2016 dari www.uin-alauddin.ac.id/
} 
Peraturan Menteri Agama RI Nomor 5 tahun 2006 tanggal 16 Maret 2006..$^{15}$

\section{b. Temuan-temuan dan pembahasan}

Penelitian ini melibatkan enam (6) dosen agama sebagai subjek penelitian. Adapun sampel penelitian dideskripsikan pada table berikut:

\begin{tabular}{|c|c|c|c|c|c|}
\hline No. & $\begin{array}{c}\text { Kode } \\
\text { Responden }\end{array}$ & $\begin{array}{c}\text { Usia } \\
\text { (tahun) }\end{array}$ & $\begin{array}{c}\text { Jenis } \\
\text { Kelamin } \\
\text { (L/P) }\end{array}$ & $\begin{array}{c}\text { Gelar } \\
\text { akademik/Jenjang } \\
\text { Pendidikan }\end{array}$ & Ket. \\
\hline 1 & P1 (M) & 45 & L & Professor & \\
\hline 2 & P2 (KT) & 44 & L & Doktor (S3) & \\
\hline 3 & P3 (MS) & 42 & L & Doktor (S3) & \\
\hline 4 & P4 (SA) & 62 & L & Magister (S2) & \\
\hline 5 & P5 (MK) & 57 & L & Magister (S2) & \\
\hline 6 & P6 (AT) & 55 & L & Magister (S2) & \\
\hline
\end{tabular}

Adapun hasil penelitian disajikan dalam tema-tema pembahasan berikut berdasarkan respon dari subjek penelitian.

\section{Tema 1. Pandangan tentang radikalisme}

Dalam memahami radikalisme perlu dipahami dua sisi yang bisa muncul. Hasil wawancara dengan beberapa responden menunjukkan bahwa paham radikal itu sifatnya normatif (sah-sah saja) dalam konteks pendalaman ilmu agama sesuai dengan ajaran yang sebenarnya dan untuk keperluan pribadi yang tidak dipaksakan ke orang lain. Paham radikal ini kemudian menjadi salah apabila dipaksakan kepada orang lain untuk mengikuti pemahaman tersebut apalagi menggunakan cara-cara yang merugikan orang lain baik secara fisik maupun psikis.

"...radikalisme kaitannya dengan usaha untuk memahami ajaran itu sifatnya positif ". Tetapi pemahaman yang belum mendalam sehingga seseorang melakukan tindakan pembunuhan, pengeboman atas nama agama itu negatif" (P1)

"Radikal boleh-boleh saja, tetapi radikalisme akan menjadi negatif ketika orang tidak sependapat dan tidak mengikutinya maka yang tidak sependapat itu dinggap salah dan harus diperangi. Mungkin sikap radikalisme 
ini karena mereka itu tidak $m$ emahami agama Islam dengan baik sebagai 'Rahamatan lil alamin'.” (P6)

“...Radikalisme bagi saya telah saya kenal. Istilah radikalisme sebenarnya adalah suatu paham yang mengarah kepada kekerasan secara pisik dan psikologis untuk memaksakan sebuah kepentingan. Karena itu di dalamnya ada keinginan untuk memaksakan kehendak, agar seseorang itu untuk mengakui dan mengikuti paham tertentu." (P2)

"...Radikal dalam menggali ajaran agama dengan sedalam-dalamnya itu positif, tetapi yang menyatakan dan menyalahkan dirinya paling benar dan orang dinyatakan salah itu sangat berbahaya. Apalagi diikuti dengan tindakan memaksakan dirinya benar dan orang lain dan kelompoknya salah." (P3)

“...Menurut pendapat saya istilah 'radikalisme' itu merupakan ide dari barat dengan maksud untuk menghacurkan bangsa Indonesia, khususnya umat Islam dengan jalan untuk Islam sendiri diaduh dengan mencipkan suatu skenario sengketa dan berselisih diantara umat Islam itu sendiri”. (P4)

Ketika paham radikalisme ini telah mengarah kepada halhal yang negatif, maka paham radikalisme telah dianggap berbahaya dan harus dicegah bahkan harus diantipati. Beberapa responden memberikan komentar sebagai berikut:

“...Radikalisme adalah paham yang ekstrim dan sangat berbahaya bahkan mereka itu melampaui batas, justru mereka harus diperangi." (P5)

“...Radikalisme ini, apabila tidak dikelola dengan baik maka akan mengarah kepada kerusakan hubungan dengan umat, bisa terjadi perpecahan.” (P2)

“...Radikalisme yang negative sangat berbahaya, karena hal itu sangat merusak tatanan hidup ditengah hidup bermasyarakat dan bernegara. ” (P3) 


\section{Tema 2. Berkembangnya paham radikalisme}

Untuk memahami isu radikalisme, pemahaman tentang proses perkembangannya menjadi hal mutlak yang juga perlu untuk diketahui. Hal ini menjadi penting karena dengan pemahaman tersebut, para insan cendekia yang memiliki keinginan untuk mencegah perkembangan lebih lanjut dari gerakan fundamentalis ini dapat menemukan titik atau kesenjangan yang bisa dimodifikasi atau diperbaiki. Dari hasil wawancara selama meneliti ditemukan pandangan-pandangan sebagai berikut:

“... untuk masalah perkembangan aliran Islam radikal ini, ada tiga teori yang bisa dijelaskan. Pertama, bahwa umat Islam diprediksikan gagal untuk memasuki persaingan era global yang menyebabkan umat Islam berfikir bahwa segala produk globalisasi, modenisasi bertentangan dengan ajaran Islam.Kedua, adanya ketidakiadilan dunia barat yang membuat umat Islam berperang antara satu dengan yang lain seperti Negara Palestina, Suriah dan lain-lain sehingga sehingga umat Islam mengambil tindakan untuk membela diri ( Islam) khususnya membela Negara Islam yang hingga saat ini dalam keadaan kacau, disinilah kaum "radikalisme" berpendapat bahwa membela Palestina adalah 'Jihad'. Ketiga, tindakan-tindakan itu adalah berhubungan dengan situasi lokal dalam (negeri) dimana Negara dianggap tidak mampu memberikan kemakmuran kepada rakyat sehingga muncul perlawanan kepada Negara..." (P1).

"....Paham dan tindakan radikalisme berkembang terutama kepada masyarakat yang lemah atau pemahaman agamanya sangat kurang." (P5)

"....Kemungkinan proses terjadinya radikalisme karena di dalam dunia pemahaman tentang Islam, umat Islam itu sendiri memang di dalamnya diberi peluang untuk memahami Islam secara pardiyah atau sendiri-sendiri, bahkan dapat terjadi adanya mereka berpendapat secara kelompok sehingga demikian bisa terjadi perselisihan dengan saling mencela kelompok yang satu kelompok yang lain. Keadaan yang demikian itulah terdapat peluang berseteru awalnya tetapi karena 
memang ada upaya untuk mengadu domba akhirnya terjadinya perselisihan pada awalnya kemudian berkembang menjadi pertikaian." (P4)

Hal menarik yang perlu digarisbawahi adalah bahwa penyebab utama berkembangnya paham radikalisme ini disebabkan karena pemahaman yang dangkal tentang ajaran agama Islam yang sebenarnya. Sebagai contoh, banyaknya kejadian teror bom di tanah air ataupun di negara-negara lain yang mengatasnamakan jihad atau memerangi kaum kafir dianggap adalah hasil kesalahan dalam menginterpretasi atau memaknai penggalan-penggalan ayat suci Al Quran. Ibrahim (2016) ${ }^{16}$ menyebutkan bahwa Islam dalam Al Quran adalah agama yang benar, Islam tidak memerlukan kekerasan atau paksaan untuk menarik pengikut, metode yang banyak digunakan dalam agama atau ajaran-ajaran yang palsu. Sangat disayangkan karena ada golongan-golongan tertentu yang sebenarnya mengetahui kebenaran dari setiap ayat Al Quran, tetapi untuk kepentingan tertentu narasi-narasi dari ayat tersebut disalah artikan sehingga termanifestasikan dalam bentuk dan perilaku yang keliru. ${ }^{17}$ Beberapa sejarah Islam yang telah disebutkan sebelumnya termasuk didalamnya gerakan kaum Khawarij, ${ }^{18,19}$ menunjukkan penggunaan kekerasan atas nama agama dengan para pemeluk gerakan yang fanatik. Pandangan teologis yang radikal diikuti oleh sikap politik yang ekstrim pula, dan berpandangan bahwa orang-orang yang tidak sependapat dengan mereka dianggap musyrik dan boleh dibunuh. ${ }^{20}$

Salah satu topik yang sering dikaitkan dengan radikalisme adalah jihad. Menurut Abdillah (2014), ${ }^{21}$ masyarakat perlu menyadari bahwa jihad kadang disalahartikan dan kadang merupakan hasil dari penafsiran berbagai individu tentang teks-teks suci dalam konteks-konteks khusus berdasarkan historis dan politis, sehingga untuk menghindari salah

\footnotetext{
${ }^{16}$ Abadir M Ibrahim, A Not-So-Radical Approach to Human Rights in Islam, The Journal of Religion, Vol. 96, No.3. 2016,346-377.

${ }^{17}$ Abadir M Ibrahim, A Not-So-Radical Approach to Human Rights in Islam, The Journal of Religion, Vol. 96, No.3. 2016,373.

18 Anzar Abdullah, Gerakan Radikalisme Dalam Islam: Perspektif Historis, ADDIN, Vol.10, No.1. Februari 2016.

19 Junaidi Abdillah, Radikalisme Agama: Dekonstruksi Tafsir Ayat-Ayat "Kekerasan" Dalam Al-Quran, Kalam: Jurnal Studi Agama dan Pemikiran Islam, Vol.8, No.2. Desember 2014.

${ }^{20} \mathrm{Ibid}$, hal 287

${ }^{21}$ Ibid, hal 290
} 
penafsiran, diperlukan pemahaman ayat-ayat Al Quran secara historis dan menyeluruh. Sebagai contoh, banyak yang menafsirkan surah Al 'Ankabut ayat 69 sebagai dasar untuk melakukan jihad dan memerangi kaum kafir:

"...Dan orang-orang yang berjihad untuk (mencari keridhaan) Kami, benar-benar akan Kami tunjukkan kepada mereka jalan-jalan Kami. Dan sesungguhnya Allah benar-benar beserta orang-orang yang berbuat baik”. Q.S 29:69.

Kata jihad juga ditemukan dalam surat at-taubah ayat 24, al-Hajj ayat 78 , al-Mumtahanah ayat 1 , al-Taubah ayat 19 , al-Hujarat ayat 1, Al'Ankabut ayat 6, akan tetapi tidak ada satu pun ayat yang memerintahkan untuk berperang dan melegalkan tindakan kekerasan dalam menyelesaikan setiap persoalan. ${ }^{22}$ Justru dalam Al Quran, surah Al-Baqarah ayat 190 menyebutkan bahwa memerangi orang lain bisa dilakukan dalam Islam tetapi ndalam konteks apabila ada sekelompok orang yang memerangi terlebih dahulu, dan juga ditekankan agar perlawanan yang diberikan tidak berlebih-lebihan.

“...Dan perangilah di jalan Allah orang-orang yang memerangi kamu, (tetapi) janganlah kamu melampaui batas, karena sesungguhnya Allah tidak menyukai orangorang yang melampaui batas." Q.S. 2:190

Di dalam lingkungan perguruan tinggi, paham radikalisme ini menjadikan mahasiswa sebagai target operasi. Hal ini sesuai dengan pernyataan dari Kemenristekdikti (2016) ${ }^{23}$ dan beberapa media nasional bahwa gerakan-gerakan Islam radikal menjadikan kampus sebagai tempat untuk menanamkan paham fundamentalisme dan merekrut anggota. Hal ini dikarenakan dalam tahap perkuliahan, mahasiswa masih mencari jati diri, penuh dengan rasa keingintahuan, dan tertantang untuk melakukan sesuatu hal yang baru, apalagi jika tidak dsertai dengan pembimbingan yang baik dan sungguh-sungguh oleh tenaga pendidik. Menurut beberapa responden:

“...mahasiswa sangat mungkin untuk disusupi paham radikal sebab disatu sisi pada saat manusia masih muda

\footnotetext{
${ }^{22}$ Ibid, hal 291-292

${ }^{23}$ Kemenristekdikti. Perkuat Ideologi Pancasila dan Agama, Cegah Paham Radikal Terorisme Masuk ke Perguruan Tinggi, 29/2/2016. Diakses pada tanggal 31 Juli 2016 dari

http://www.dikti.go.id/perkuat-ideologi-pancasila-dan-agama-cegah-paham-radikalterorisme-masuk-ke-perguruan-tinggi/
} 
mereka rentan untuk ikut-ikutan dalam sebuah paham yang tidak diketahui dan disisi lain terkait dengan system pertahanan dan ketahanan lingkungan masyarakat”. (P1) "....Radikalisme pasti akan berkembang manakala seseorang itu tidak memahami secara filosopi atau memahami ide baru itu. Apalagi mahasiswa itu kadang bersifat panatisme atau paham etnosentrisme untuk mendewakan suku, ide-ide tertentu. Di kalangan mahasiswa, berkembangnya paham ini bisa jadi karena mahasiswanya tidak dimbimbing dengan baik dan pengawasan secara sungguh-sungguh". (P2)

\section{Tema 3. Peran dosen dalam mengantisipasi perkembangan gerakan radikalisme}

Secara umum, para responden menaruh perhatian yang besar untuk isu perkembangan paham radikalisme yang bersifat negatif. Memberikan pencerahan kepada mahasiswa tentang bahaya laten gerakan-gerakan radikal yang ekstrim cukup menjadi prioritas responden, sementara ada beberapa responden yang menyatakan bahwa memberikan pemahaman kepada mahasiswa lebih mudah dilakukan daripada memberikan pesan dakwah kepada masyarakat umum tentang gerakan-gerakan fundamentalis ini.

"...Anti Radikalisme banyak disampaikan kepada mahasiswa setiap kali mengajar. Selain itu isu radikalisme ini ini juga harus dibendung dengan banyak menyampaikan melaui ceramah dan khutbah di Masjidmasjid, terutama sifat toleransi di publikasikan dan disampaikan. Masyarakat harus ketahui bahwa Islam adalah "Rahmatan Lil Alamin". Contoh kehidupan Rasulullahsaw. Yang memahami dan menghargai orang lain " Hal ini terjadi pada ketika Rasulullah betindak sebagai kepala Negara dmereka Yahudi tahanan dihargai bahkan dilindungi." (P3)

"....Radikalisme ini senantiasa di dakwahkan kepada masyarakat, melalui ceramah, khutbah disetiap masjid." (P5)

“....Masalah ini senantiasa diangkat ditengah mahasiswa dan masyarakat umum. Terutama kepada mahasiswa, sangat perlu menagarahkan mereka sebagai generasi pembangun dan penentu masa depan umat." (P1) 
“...Berhadapan dengan mahasiswa sering, kalau berhadapan dengan masyarakat pesan agama tentang larangan bersifat radikalisme itu dilakukan, dilakukan melalui khutbah, dan ceramah. Tetapi penjelasan 'masalah radikalisme" tidak bisa tuntas, sehingga memungkinkan akan timbulnya kesalahpahaman saja. Menyampaikan pesan agama harus senantiasa dilakukan kepada masyarakat, karena seseorang yang semakin banyak mengetahui dan mendalami berbagai masalah agama maka orang tersebut lebih tawadhu/rendah hati dan lebih ikhlas dan lebih toleran. Contoh ketikaa seorang memiliki pandangan yang lebih luas dan mendalam maka seseorang itu lebih menerima dan lebih toleran terhadap agamaagama yang lain selain dari dirinya." (P6)

\section{Tema 4. Upaya menangkal perkembangan radikalisme di kalangan mahasiswa}

Terdapat keragaman pandangan dari responden dalam hal upaya mengantisipasi berkembangnya paham radikalisme di tengah-tengah mahasiswa. Usaha menangkal bahaya radikalisme di kalangan mahasiswa cukup baik sehingga upaya mengantisipasi perkembangan paham radikal juga dapat terbangun sejak awal. Pada akhirnya, perkembangan radikalisme negatif dapat ditekan. Beberapa pandangan responden dapat dilihat sebagai berikut:

“...Sistem pebelajaran harus diperbaiki, selanjutnya harus kontrol terhadap kegiatan-kegiatan akademik kemahasiswaan harus juga dikawal secara baik serta penguatan budaya kepada mahasiswa dengan menjunjung tinggi nilai-nilai yang baik harus digalakkan setiap saat." (P1)

"....Mengajarkan kebenaran dihadapan mahasiswa di kampus itu harus lebih komunikatif dapat terarah kepada kepada terbentuknya 'jati diri mereka'. Sering-sering mengajarkan ajaran tentang 'non-radikalisme' dengan tujuan agar mereka dapat menghindari paham-paham 'radikalisme' itu sendiri. Contoh konkrit langkah-langkah yang dapat ditempuh untuk dapat meredam sifat 'radikalisme' setiap 15 menit setelah mahasiswa masuk kelas dilakukan pencerahan. Dan itu dilakukan secara terus menerus kepada mahasiswa. Akan tetapi berbeda 
untuk pembinaan di dalam masyarakat, sebaiknya diadakan suatu bentuk 'pengajian saja'." (P6)

"...Hal-hal yang perlu dikembangkan untuk meredam terjadinya radikalisme dikalangan mahasiwa dan masyarakat adalah sebagai berikut: mengembangkan 'KEBINHEKATUNGGALIKAAN', mewujudkan slogan 'Islam Nusantara' membuka ruang komunikasi dengan segenap organisasi." (P2)

“....Usaha menangkalnya di kalangan mahasiswa dapat berupa: meningkatkan usaha mendalami metodologi berpikir, setiap dosen memberi perhatian dan mendukung CBT di kampus, melestarikan kearifan 'lokal' yang ada pada setiap daerah, pelatihan bersama melalui pendidikan di alam luar, serta pada setiap institusi kampus harus memberikan fasilitas dan membuka ruang "public service" untuk senantiasa berdialog. " (P4)

“....Mengajarkan ke mahasiswa dan masyarakat tentang metode berfikir yang membangun sikap saling menghargai dan sikap memahami keniscayaan." (P3)

“....Untuk itu penting mengajarkan kepada mahasiswa tentang anti radikalisme, untuk selalu ada inisiatif untuk mendalami agama serta untuk selalu membangun metodologi berpikir dalam bentuk yang sangat bi al hikmah." (P5)

Dari respon di atas, dapat dilihat bahwa dosen di perguruan tinggi agama dapat melakukan peran penting dengan menggiatkan pendidikan memahami ajaran agama secara utuh, sehingga mampu membentuk jati diri dan karakter mahasiswa yang murni Islam dan tidak mengarah kepada paham radikal yang tidak diinginkan termasuk yang melibatkan unsur paksaan dan kekerasan. Menurut Sahrodi (2008), ${ }^{24}$ salah satu pendekatan dalam memahami ajaran agama yang sesungguhnya dapat dilakukan dengan pendekatan antropologis yang diartikan sebagai suatu upaya memahami agama dengan cara melihat wujud praktik keagamaan yang tumbuh dan berkembang dalam masyarakat. Melalui pendekatan ini, agama tampak akrab dan dekat dengan masalah-masalah yang dihadapi manusia dan berupaya menjelaskan serta memberikan jawabannya.

\footnotetext{
${ }^{24}$ Jamali Sahrodi, Metodologi Studi Islam: Menelusuri Jejak Historis Kajian Islam ala Sarjana Orientalis. (Bandung: Pustaka Setia, 2008).
} 
Dengan kata lain bahwa cara-cara yang digunakan dalam melihat sebuah masalah dapat pula digunakan untuk memahami agama. Dalam hal ini Sahrodi (2008) ${ }^{25}$ menyebutkan bahwa Islam seharusnya tidak lagi dipandang sebagai agama yang inklusif. Artinya, Islam sebagai sebuah ajaran, agama, doktrin dan sebuah keyakinan sangat terbuka untuk dikaji, baik melalui penelitian maupun kajian-kajian akadmeik lainnya. Hal ini nampaknya menunjukkan sebuah fakta bahwa Islam sebagai agama yang mengayomi seluruh umat manusia menjadi realitas yang terbuka dalam pembuktiannya.

Menurut Nazir $(2015)^{26}$, nilai-nilai yang perlu ditanamkan kepada mahasiswa adalah bahwa nilai misi keagamaan yakni semua agama membawa misi kedamaiaan, termasuk agama Islam. Oleh karena itu Islam sebagai suatau agama oleh umatnya harus dipahami sebagai agama damai. Dalam al Qur`an dan Sunnah Nabi ditemukan banyak dalil yang bersifat qat iyah mengenai larangan berbuat binasa di atas bumi (wala tufsidu flu ardhi), termasuk di dalamnya menumpahkan darah. Adanya larangan menumpahkan darah bagi umat manusia (Islam) tersebut karena Islam sangat menghargai jiwa manusia, bahkan demi menjaga jiwa manusia, dalam perang-pun Allah melalui Nabinya Muhammad s.a.w., membuat aturan dan etika berperang yang harus diamalkan oleh tentara muslim ketika melawan musuh-musuhnya. Sebagai gambaran dan prakteknya sehari-hari dapat dilihat perbuatan dan ucapan khalifah pertama Abu Bakar Siddiq (w.th 13/634 M) ketika melepaskan bala tentara dalam rangka menaklukkan negeri Syria. Beliau berkata; "Kalau kamu memasuki negari itu kamu tidak boleh membunuh orang tua atari anak-anak... Ciptakanlah perjanjian dengan setiap kota dan rakyatnya yang menerimamu, berilah mereka jaminan, dan biarkanlah mereka hidup sesuai dengan aturan hukum mereka.....Bagi mereka yang tidak menerimamu, kamu harus berjuang berbuatlah kamu dengan hati-hati, sesuai dengan aturan dan hukum yang telah diturunkan oleh Allah kepadamu melalui Nabinya Muhammad s.a.w. ” Dan ucapan Abu Bakar Siddig di atas terlihat, betapa tingginya harkat dan martabat atau nilai-nilai kemanusian di mata Islam karena tujuan diturunkannya syari’at Islam salah satu di antaranya adalah

\footnotetext{
${ }^{25}$ Ibid

${ }^{26}$ M Nasir, Peran Lembaga Pendidikan Dan Budaya Lokal Dalam Menanggulangi Gerakan Radikalisme, 16/2/2015. Diakses pada tanggal 1 Juli 2016 dari http://pascauinsuska.info/dosen-131-peran-lembaga-pendidikan-dan-budaya-lokaldalammenanggulangi-gerakan-radikalisme.html
} 
untuk menjaga jiwa manusia. ${ }^{27}$ Allah SWT menekanka dalam Surat at Maidah ayat 32:

"Barang siapa yang membunuh seorang manusia bukan karena orang au membunuk orang lain atau bukan karena membuat kerusakan di atas bumi, maka seakan-akan dia telah membunuh manusia seluruhnya. Dan barang siapa memelihara kehidupan seorang manusia, maka seolaholah dia telah menjaga kehidupan manusia seluruhnya." (Q:5:32).

\section{Kesimpulan}

Gerakan-gerakan Islam fundamentalis atau yang dikenal sebagai gerakan paham radikal telah menjadi tantangan tersendiri bagi umat Islam di seluruh dunia termasuk di Indonesia. Meskipun paham radikal ini sifatnya normatif jika dilakukan sesuai dengan kaidah kefundamentalismean (mendalami ajaran agama untuk perbaikan diri pribadi), munculnya berbagai kejadian bersifat radikal yang mengatasnamakan agama dan Tuhan telah memberikan gambaran bahwa kekerasan itu seakan-akan diperbolehkan dalam Islam.

Kesimpulan dari penelitian ini adalah sebagai berikut. Pertama, paham radikal dapat dikategorikan sebagai hal yang positif tetapi dengan ketentuan digunakan untuk mendalami agama untuk kepentingan sendiri dan tidak dipaksakan ke orang lain apalagi seharusnya tidak merugikan orang lain baik dalam bentuk fisik maupun kejiwaan. Apabila hakikat dari makna positif tersebut telah melampaui hal-hal normatifnya, apalagi menimbulkan kerugian bagi orang lain termasuk penggunaan kekerasan, maka paham ini telah menjadi sangat berbahaya sehingga harus diantisipasi, dicegah, dilawan atau bahkan diperangi secara terangterangan. Kedua, berkembangnya paham radikalisme ini pada dasarnya disebabkan karena kurangnya pemahaman mendalam tentang nilai-nilai Islam dan ajaran keagamaan yang sesungguhnya. Mahasiswa di perguruan tinggi menjadi sangat rentan untuk dijadikan target pengembangan gerakan-gerakan radikalisme tersebut karena factor usia kematangan pribadi, pencarian jati diri serta rasa keingintahuan dan mencoba hal-hal

\footnotetext{
${ }^{27}$ M Nasir, Peran Lembaga Pendidikan Dan Budaya Lokal Dalam Menanggulangi Gerakan Radikalisme, 16/2/2015. Diakses pada tanggal 1 Juli 2016 dari http://pascauinsuska.info/dosen-131-peran-lembaga-pendidikan-dan-budaya-lokaldalammenanggulangi-gerakan-radikalisme.html
} 
baru dan menantang. Ketiga, pada dasarnya dosen di perguruan tinggi telah menyadari tantangan ini sehingga dakwah, baik formil maupun non-formil (pendekatan kemahasiswaan) sudah sering dilaksanakan dengan tujuan membekali mahasiswa dengan pengetahuan tentang bahaya gerakan radikalisme. Keempat, perguruan tinggi harus turut berperan aktif dalam mengantisipasi perkembangan gerakan Islam radikal melalui penanaman nilai-nilai agama yang komprehensif, termasuk mengajarkan nilai-nilai pluralistic, melatih pola pemikiran yang logis dan ilmiah, serta memfasilitasi terbukanya forum-forum dialog terbuka untuk mahasiswa sebagai wadah untuk bertukarfikiran serta menetralisir segala bentuk paham-paham negatif berbau radikal yang sedang berkembang. Harapannya, paham radikalisme dapat dicegah untuk berkembang di dalam lingkungan perguruan tinggi serta menyiapkan masa depan yang baik bagi para penerus bangsa.

Sebagai salah satu dari sedikit penelitian lapangan terkait isu radikalisme di Indonesia, penelitian ini tentu saja memiliki keterbatasan. Jumlah responden yang sangat terbatas (enam orang) mengakibatkan adanya keterbatasan variasi respon yang diberikan oleh responden yang juga memiliki dampak bagi kesimpulan atau temuan dari penelitian ini. Walaupun dalam penelitian kualitatif tidak ada batasan untuk jumlah sampel, jumlah sampel yang lebih besar tentunya memiliki efek positif yang besar bagi kayanya informasi yang bisa didapatkan untuk dijadikan atau menegaskan tema-tema pembahasan penelitian. Oleh karena itu diharapkan penelitian lanjutan ataupun yang sejenis dapat menyediakan jumlah sampel yang lebih banyak.

\section{DAFTAR PUSTAKA}

Abdillah, Junaidi, 2014. "Radikalisme Agama: Dekonstruksi Tafsir AyatAyat "Kekerasan" Dalam Al-Quran”, Kalam: Jurnal Studi Agama dan Pemikiran Islam, Vol.8, No.2.

Abdullah, Anzar, 2016. "Gerakan Radikalisme Dalam Islam: Perspektif Historis", ADDIN, Vol.10, No.1.

Afadlal., Irawati, Awani., Mashad, Dhurorudin., Zaenuddin, Dundin., Purwoko, Dwi., Turmudi, Endang., Hisyam, Muhammad., \& Sihbudi, Riza, 2005. Islam dan Radikalisme di Indonesia. Jakarta: LIPI Press. 
Al Quran Al Karim.

Cleary, M., Horsfall, J., \& Hayter, M., 2014. "Data Collection and Sampling In Qualitative Research: Does Size Matter?”, Journal of Advanced Nursing, Vol.70, No.3.

CNN Indonesia (Kontributor: Armenia, Resty). Bahas Radikalisme, Jokowi Minta NU Jadi Benteng. Tersedia online sejak 26 Februari 2015. Diakses pada tanggal 16 Juli 2016 dari http://www.cnnindonesia.com/politik/20150226135404-3235102/bahas-islam-radikal-jokowi-minta-nu-jadi-benteng/

CNN Indonesia (Kontributor: Gumilang, Prima). Radikalisme Ideologi Menguasai Kampus. Tersedia online sejak 18 Februari 2016. Diakses pada tanggal $30 \quad$ Juli 2016 dari http://www.cnnindonesia.com/nasional/20160218193025-12111927/radikalisme-ideologi-menguasai-kampus/

Direktorat Jenderal Pembelajaran dan Kemahasiswaan Kemenristekdikti. General Education Salah Satu Model dalam Mencegah Radikalisme di Lingkungan Perguruan Tinggi. Tersedia online sejak 14 Maret 2016. Diakses pada tanggal 31 Juli 2016 dari http://belmawa.ristekdikti.go.id/2016/03/14/general-educationsalah-satu-model-dalam-mencegah-radikalisme-di-lingkunganperguruan-tinggil

Gentles, S. J., Charles, C., Ploeg, J., \& McKibbon, K. A., 2015 "Sampling In Qualitative Research: Insights From An Overview of the Methods Literature", The Qualitative Report, Vol.20, No.11.

Hitti, Phillip K.,1974. History of the Arabs. Edisi 10, London: The Macmillan Press LTD, 1974.

Ibrahim, Abadir M., 2016. "A Not-So-Radical Approach to Human Rights in Islam", dalam The Journal of Religion, Vol. 96, No.3.

Karagiannis, Emmanuele \& McCauley, Clark, 2007. "Hizb ut-Tahrir alIslami: Evaluating the Threat Posed by a Radical Islamic Group That Remains Nonviolent", Terrorism and Political Views, Vol.18, No.2.

Kemenristekdikti. Perkuat Ideologi Pancasila dan Agama, Cegah Paham Radikal Terorisme Masuk ke Perguruan Tinggi. Tersedia online sejak 29 Februari 2016. Diakses pada tanggal 31 Juli 2016 dari 
http://www.dikti.go.id/perkuat-ideologi-pancasila-dan-agamacegah-paham-radikal-terorisme-masuk-ke-perguruan-tinggi/

Liamputtong, Pranee, 2013. Qualitative Research Methods (Edisi ke-4.). Melbourne: OXFORD University Press.

Nahdlatul Ulama. Radikalisme Islam di Indonesia. Tersedia online sejak 28 Oktober 2008. Diakses pada tanggal 15 Juli 2016 dari http://www.nu.or.id/post/read/14454/radikalisme-islam-diindonesia

Nasir, M. Peran Lembaga Pendidikan Dan Budaya Lokal Dalam Menanggulangi Gerakan Radikalisme. Tersedia online sejak 16 Februari 2015. Diakses pada tanggal 1 Juli 2016 dari http://pascauinsuska.info/dosen-131-peran-lembaga-pendidikan-dan-budayalokaldalam-menanggulangi-gerakan-radikalisme.html

Sahrodi, Jamali, 2008. Metodologi Studi Islam: Menelusuri Jejak Historis Kajian Islam ala Sarjana Orientalis. Bandung: Pustaka Setia.

Siregar, Hamka, 2015. "Peran IAIN Pontianak Dalam Mencegah Paham Radikalisme Agama" dalam AT-TURATS, Vol.9 No. 1.

UIN Alauddin Makassar. Profil UIN Alauddin Makassar. Diakses pada tangal 1 Juli 2016 dari www.uin-alauddin.ac.id/

UIN Syarif Hidayatullah. MUI, NU, Muhammadiyah Jadi Musuh Gerakan Islam Radikal. Tersedia online sejak 6 Februari 2016. Diakses pada tanggal 10 Juli 2016 dari http://www.uinjkt.ac.id/id/mui-numuhammadiyah-jadi-musuh-gerakan-islam-radikal/

Ummah, Choirul Sun, 2012. "Akar Radikalisme Islam di Indonesia", Humanika Vol.12, No.1.

Unair News. Kampus Jadi Tempat Kaderisasi Paham Radikal. Tersedia online sejak 26 Maret 2016. Diakses pada tanggal 1 Agustus 2016 dari http://news.unair.ac.id/2016/03/26/kampus-jadi-tempatkaderisasi-paham-radikal/

Undang-Undang Republik Indonesia Nomor 12 Tahun 2012 tentang Pendidikan Tinggi.

Zainuddin, M. Memantapkan Peran Dosen.Tersedia online sejak 8 November 2013. Diakses pada tanggal 15 Juli 2016 dari http://zainuddin.lecturer.uinmalang.ac.id/2013/11/08/memantapkan-peran-dosen/ 